\title{
BIOMETRIC INDICATORS OF LINES - PARENTS OF MAIZE HYBRIDS OF DIFFERENT FAO GROUPS DEPENDING ON BIOLOGICAL TREATMENT ON IRRIGATION
}

\author{
Marchenko T., Vozhegova R., Lavrynenko Y., Zabara P. \\ Institute of Irrigated Agriculture of the National Academy of Agrarian Sciences, Ukraine
}

Biometric indicators and seed yields of parents of modern domestic maize hybrids of different ripeness grown at various plant densities on drip irrigation in the Southern Steppe and treated with biologicals have been determined. The relationships between the plant height and the attachment height of the upper (productive) cob with the seed yields in the lines -parents of hybrids have been established. The study has shown that treatment of maize plants with biologicals positively affected the plant height, attachment height of the upper cob and yield in the parents of maize hybrids. Early-ripening line DK 281 (FAO 190) gave the maximum yield at a plant density of 90,000 plants/ha and Helafit combi treatment - 3.65 t/ha. Mid-early line DK 247 (FAO 290) gave the maximum yield at a density of 80,000 plants/ha and Helafit combi treatment $-4.65 \mathrm{t} / \mathrm{ha}$. Mid-late lines DK 445 and DK 411 gave the maximum yields at a density of 70,000 plants/ha and Helafit combi treatment $-6.30 \mathrm{t} / \mathrm{ha}$ and $4.65 \mathrm{t} / \mathrm{ha}$, respectively.

\section{Key words: maize, parent, plant height, attachment height of upper (productive cob), yield}

Introduction. In modern technologies for maize growing, environmentally friendly elements based on the use of biological agents are becoming increasingly important. Application of high doses of mineral fertilizers and chemical plant protectors without sufficient scientific justification and in violation of an application technology can have very dangerous consequences to the environment. Modern biologicals can be an alternative to high doses of mineral fertilizers. Biologicals, when used in modern technologies, are important for agricultural crop yields $[1,2]$.

Literature review and problem articulation. Industrial-scale cultivation of new hybrids with high performance potential is a guarantee of the grain production stabilization in Ukraine. It is known that it is possible to increase maize grain yields by $\geq 50 \%$ due to heterosis [3-5]. The creation of intensive high-yielding hybrids is an important avenue of domestic breeders' work [6]. To fulfill the performance potential of a hybrid or a parent, one has to artificially create certain growing conditions through agronomic measures, taking into account the demands of plants to environmental factors in general [7]. Given that recently the quantitative and qualitative assortment of maize hybrids included in the Register of Plant Varieties of Ukraine has expanded significantly, it is necessary to improve both individual technological elements and the whole technologies for growing hybrid parents to provide the required numbers of seeds for hybridization. The plant density plays an important role in the complex of agrotechnical measures for maize growing, on which the seed yield depends. A considerable yield can be harvested due to high individual performance and the maximum allowable density of plants in a particular site of cultivation. Depending on agroecological conditions, individual morphobiological features of hybrids, water supply, nutrition and other factors, the optimal number of maize plants in the fields varies 40,000/ha for late-ripening forms to $\geq 100,000 /$ ha for early-ripening ones. Thickening or thinning causes changes in temperature, water, heat, and light modes in the fields [8]. Maize is characterized by slow initial growth, poorly developed root system and low water consumption coefficient during the early stages of the growing period. It is during this period it hardly responds to thickening or thinning. During the subsequent stages of ontogenesis, the plant density significantly affects the growth, development and performance of maize plants [9]. The maize plant height is an important biometric features, which can be used to determine the response of plants to changes in their growing conditions, which in turn are formed under the influence of a growing technology and environmental factors. The plant height gain clearly reflects the endogenous processes occurring in

(C) T. Marchenko, R. Vozhegova, Y. Lavrynenko, P. Zabara. 2021.

ISSN 1026-9959. Селекція і насінництво. 2021. Випуск 119 
plants. One can conclude about the effect of one or another factor on plants from the height gain $[10,11]$.

Further improvement of maize cultivation technologies is possible via introduction of new high-yielding hybrids of different ripeness groups and refinement of existing agronomic measures aimed at fulfilling the genetic potential of heterosis forms in relation to a specific soil-climatic zone [12]. Hybrids of a certain biotype respond differently to environmental conditions changing under the influence of hydrothermal parameters and phytoclimate of the fileds, which in turn are determined by technological measures of maize cultivation - sowing timeframe and plant density [13].

It is known that the suitability for mechanized harvesting depends on the following morphological features of maize: the plant height and the attachment height of cobs [14]. For mechanized cultivating and harvesting maize hybrids, the attachment height of cobs is of the utmost importance. This feature is determined by biological characteristics of plants and growing conditions. When maize is harvested mechanizedly, even arrangement of cobs at an optimal height is important, because a low attachment of cobs $(30-50 \mathrm{~cm})$ leads to considerable losses of grain during mechanized harvesting $(15-20 \%$ or more), but a attachment of cobs (above $110 \mathrm{~cm}$ ) is also undesirable due to increased harvesting costs $[15,16]$. Several researchers reported that the attachment height of cobs was genetically determined and significantly influenced by elements of agricultural technologies and environmental conditions. There are publications that the attachment height of cobs closely and positively correlates with the plant height $[17,18]$. The plant height and attachment height of cobs in maize are integral biological features of hybrids and are always in certain proportions with other morphological features that are intrinsic to a certain ripeness group of hybrids. They are determining indicators of the plant response to growing conditions [19]. These features affect the quality and speed of harvesting, energy consumption and quality indicators of grain and seeds [20].

Purpose and objectives. Our purpose was to determine biometric indicators and seed yields of parents of modern domestic maize hybrids belonging to different ripeness groups, grown at various plant densities on drip irrigation in the Southern Steppe and treated with biologicals; to evaluate the relationships between the plant height and the attachment height of the upper (productive) cob with the seed yield in the lines - parents of hybrids.

Materials and methods. The study was conducted in the experimental field the Institute of Irrigated Agriculture of NAAS located in the area of Inhuletkyi irrigation system in 2018-2020. The soil in the experimental site is dark-chestnut, medium loamy, slightly alkalinized, with deep groundwater levels.

The design of a three-factor experiment was randomized split blocks, in quadruplicate. The sown plot area was $30.0 \mathrm{~m}^{2}$; the record area was $20.0 \mathrm{~m}^{2}$.

Factor A - lines-parents of different ripeness groups: DK 445 (parent of hybrids Arabat, Vira, Hileia), DK 411 (parent of hybrids Chonhar, Lamasan), DK 281 (parent of hybrid Stepovyi), and DK 247 (parent of hybrid Skadovskyi). Factor B - plant density of the parents (70,000, 80,000 and 90,000 plants/ha). Factor C - treatment of the parents with biologicals: Bio-gel and Helafit combi, which are in the Permitted Pesticide Register.

The farming techniques and study methods are conventional for irrigation, except for the factors under investigation. Drip irrigation was used, with the pre-irrigation water content of $80 \%$ of the minimum moisture-holding capacity in the $0-50 \mathrm{~cm}$ soil layer $[21,22]$.

Helafit combi: bioagent; main active ingredients: trace elements, ions of biogenic metals, free amine acid, humates, fatty acids, fatty acid esters, polysaccharides, steroid glucosides, vitamins, 3indoleacetic acid, epibrassinolide, zeatin, alginic acid, andhydroxycinnamic acid. It is applied in 2 steps: during the '7-8 leaves' phase and paniculation.

Bio-gel: organic fertilizer; main active ingredients: nitrogen, amino acids (threonine), phosphorus oxide, potassium oxide, manganese, zinc, molybdenum, copper, cobalt, saprophytic microorganisms. Seeds were treated at a dose of $2 \mathrm{~L} / \mathrm{t}$, and plants were sprayed at a dose of $1.5 \mathrm{~L} / \mathrm{ha}$ during the '7-8 leaves' phase.

Results and discussion. The plant height of parents of hybrids in maize depending on plant density and treatment is of great utilitarian importance in combination with seed yield. The optimal 
biometric parameters of the maize lines were determined for individual FAO groups.

Analysis of the data in Table 1 shows that plant height varied depending on the genotype of a parent, plant density and treatment with the biologicals.

Table 1

Plant height in the parents of maize hybrids depending on plant density and treatment with the biologicals, $\mathrm{cm},(2018-2020$ average)

\begin{tabular}{|c|c|c|c|c|c|c|}
\hline \multirow{2}{*}{$\begin{array}{c}\text { Parent } \\
\text { (factor A) }\end{array}$} & \multirow{2}{*}{$\begin{array}{l}\text { Plant height, } \\
\text { plants/ha } \\
\text { (factor B) }\end{array}$} & \multicolumn{3}{|c|}{$\begin{array}{l}\text { Biological treatment } \\
\text { (factor } \mathrm{C})\end{array}$} & \multicolumn{2}{|c|}{ Factor average } \\
\hline & & $\begin{array}{l}\text { Control (no } \\
\text { treatment) }\end{array}$ & Bio-gel & $\begin{array}{l}\text { Helafit } \\
\text { combi }\end{array}$ & A & B \\
\hline \multirow{3}{*}{$\begin{array}{c}\text { DK } 281 \\
(\text { FAO 190) }\end{array}$} & 70,000 & 186.2 & 187.5 & 188.3 & \multirow{4}{*}{189.8} & 187.6 \\
\hline & 80,000 & 186.9 & 188.6 & 189.3 & & 188.0 \\
\hline & 90,000 & 192.5 & 193.3 & 195.7 & & 193.8 \\
\hline Mean & & 188.5 & 189.8 & 191.1 & & \\
\hline \multirow{3}{*}{$\begin{array}{c}\text { DK } 247 \\
(\text { FAO 290) }\end{array}$} & 70,000 & 207.8 & 208.6 & 210.7 & \multirow{4}{*}{213.3} & 209.0 \\
\hline & 80,000 & 211.8 & 213.5 & 216.2 & & 213.8 \\
\hline & 90,000 & 215.2 & 217.3 & 218.8 & & 217.1 \\
\hline Mean & & 211.6 & 213.1 & 215.2 & & \\
\hline \multirow{3}{*}{$\begin{array}{c}\text { DK } 411 \\
(\text { FAO 420) }\end{array}$} & 70,000 & 176.3 & 178.5 & 179.3 & \multirow{4}{*}{183.2} & 178.0 \\
\hline & 80,000 & 182.6 & 183.4 & 185.8 & & 183.9 \\
\hline & 90,000 & 186.9 & 187.7 & 188.5 & & 187.7 \\
\hline Mean & & 181.9 & 183.2 & 184.5 & & \\
\hline \multirow{3}{*}{$\begin{array}{l}\text { DK } 445 \\
(\text { FAO 420) }\end{array}$} & 70,000 & 185.5 & 187.3 & 188.8 & \multirow{4}{*}{189.5} & 187.2 \\
\hline & 80,000 & 188.1 & 190.4 & 191.3 & & 189.9 \\
\hline & 90,000 & 190.7 & 192.8 & 194.3 & & 192.6 \\
\hline Mean & & 188.1 & 190.2 & 191.5 & & \\
\hline $\begin{array}{l}\text { Factor } \mathrm{C} \\
\text { average }\end{array}$ & & 192.5 & 194.1 & 195.6 & & \\
\hline \multicolumn{7}{|c|}{ Significance of differences } \\
\hline \multicolumn{2}{|c|}{$\mathrm{LDS}_{05}, \mathrm{t} / \mathrm{ha}$} & $\mathrm{A}=1$ & $.73 ; \mathrm{B}=$ & $1.39 ;$ & $7-1.45$ & \\
\hline
\end{tabular}

The study revealed that the most intense linear growth processes in maize plants occurred before the anthesis. During the anthesis, there was a significant increase in the plant height, depending on the experimental variant. The plant height of the parents of different ripeness groups ranged 176.3 to $215.2 \mathrm{~cm}$ in the control.

The ripeness group of the parents was shown to have no effect on the plant height at different stages of their growth and development. On average, midd-early line DK 247 (FAO 290) was the tallest $(213.3 \mathrm{~cm}$ ), while mid-late lines DK 411 and DK 445 (FAO 420) were the lowest (183.2 and $189.5 \mathrm{~cm}$, respectively). The plant height in the lines - parent depended rather on the genotype than on the FAO group.

The plant height varied depending on the plant density. The obtained data allowed us to identify some peculiarities of the response of the maize lines to the plant density. The plants were tallest during the anthesis in the maximally thickenined plots. Reduction in the plant density led to a decrease in the plant height. This pattern was observed in all the lines. The linear growth in the thickened plots was boosted due to the aggravation of competitive relations between plants in the agrocenosis with sufficient moisture. The DK 281 plants became $2.3 \%$ taller with increasing the density from 70,000 to 90,000 plants/ha; in DK247 plants $-4.9 \%$ taller, DK 411 plants $-4.9 \%$ taller; DK 445 plants $-3.1 \%$ taller.

Treatment of maize plants with biologicals had a positive effect on the height of the parent during stages of development. Helafit forte had the greatest effect on growth processes, since it increased the plant height by $1.9-3.8 \mathrm{~cm}$ compared to the control. Bio-gel, on average, had a minimal effect on growth processes (an increase by $0.3-2.4 \mathrm{~cm}$ ). 
The attachment height of the productive (upper) cob is an indicator of the production ease of lines - parents of maize hybrids, as a low location leads to significant losses upon combine harvesting. The cob attachment height varied in a fairly wide range -92.6 to $106.3 \mathrm{~cm}$ (Table 2). The upper cob was attached highest in mid-early line DK 247 and lowest in mid-late line DK 411. The biologicals increased the cob attachment height by $0.6-1.8 \mathrm{~cm}$.

Like the plant height, the cob attachment height varied: in thickened plots, cobs were higher on plant stems than in thinned ones. There was a close correlation between the plant height and cob attachment height $(\mathrm{r}=0.862)$.

Table 2

Attachment height of the productive (upper) cob in the parents of maize hybrids depending on plant density and treatment with the biologicals, $\mathrm{cm},(2018-2020$ average)

\begin{tabular}{|c|c|c|c|c|c|c|}
\hline \multirow{2}{*}{$\begin{array}{c}\text { Parent } \\
\text { (factor A) }\end{array}$} & \multirow{2}{*}{$\begin{array}{c}\text { Plant height, } \\
\text { plants/ha } \\
\text { (factor B) }\end{array}$} & \multicolumn{3}{|c|}{$\begin{array}{l}\text { Biological treatment } \\
\quad(\text { factor } \mathrm{C})\end{array}$} & \multicolumn{2}{|c|}{ Factor average } \\
\hline & & Control (no & Bio-gel & Helafit & A & B \\
\hline DK 281 & 70,000 & 92.6 & 93.1 & 94.3 & & 93.3 \\
\hline \multirow{2}{*}{ (FAO 190) } & 80,000 & 93.8 & 94.2 & 95.1 & 94.4 & 94.4 \\
\hline & 90,000 & 94.5 & 95.1 & 96.7 & & 95.4 \\
\hline Mean & & 93.6 & 94.1 & 95.4 & & \\
\hline DK 247 & 70,000 & 100.1 & 100.5 & 101.1 & & 100.6 \\
\hline \multirow[t]{2}{*}{ (FAO 290) } & 80,000 & 100.9 & 101.1 & 102.2 & 102.5 & 101.4 \\
\hline & 90,000 & 105.1 & 105.5 & 106.3 & & 105.6 \\
\hline Mean & & 102.0 & 102.4 & 103.2 & & \\
\hline \multirow{3}{*}{$\begin{array}{c}\text { DK } 411 \\
(\text { FAO 420) }\end{array}$} & 70,000 & 83.7 & 84.1 & 85.9 & & 84.6 \\
\hline & 80,000 & 84.5 & 85.1 & 86.3 & 86.1 & 85.3 \\
\hline & 90,000 & 87.5 & 88.3 & 89.7 & & 88.5 \\
\hline Mean & & 85.2 & 85.8 & 87.3 & & \\
\hline DK 445 & 70,000 & 92.5 & 94.3 & 95.3 & & 94.0 \\
\hline \multirow[t]{2}{*}{ (FAO 420) } & 80,000 & 93.8 & 94.6 & 95.6 & 95.2 & 94.7 \\
\hline & 90,000 & 95.9 & 96.8 & 97.9 & & 96.9 \\
\hline \multicolumn{2}{|l|}{ Mean } & 94.1 & 95.2 & 96.3 & & \\
\hline \multicolumn{2}{|l|}{$\begin{array}{l}\text { Factor } \mathrm{C} \\
\text { average }\end{array}$} & 93.8 & 94.4 & 95,6 & & \\
\hline \multicolumn{7}{|c|}{ Significance of differences } \\
\hline \multicolumn{2}{|c|}{$\mathrm{LDS}_{05}, \mathrm{t} / \mathrm{ha}$} & \multicolumn{5}{|c|}{$\mathrm{A}=1.52-1.84 ; \mathrm{B}$} \\
\hline
\end{tabular}

The ability to evaluate the effects of individual biometric indicators on the seed yields from maize lines is an important aspect of the experiment. There was no correlation between the plant height and seed yield in the parental lines (Fig. 1). Thus, during the milky ripeness phase, the correlation coefficient between the plant height and grain yields from hybrids was 0.021 .

This confirms the preliminary conclusion that the the genotype of a parent is the main factor in for seed yield, and the plant height indirectly affects it through the potential performance of genotypes. $=0.155)$.

There was a weak correlation between the cob attachment height and seed yield in the lines ( $\mathrm{r}$ 


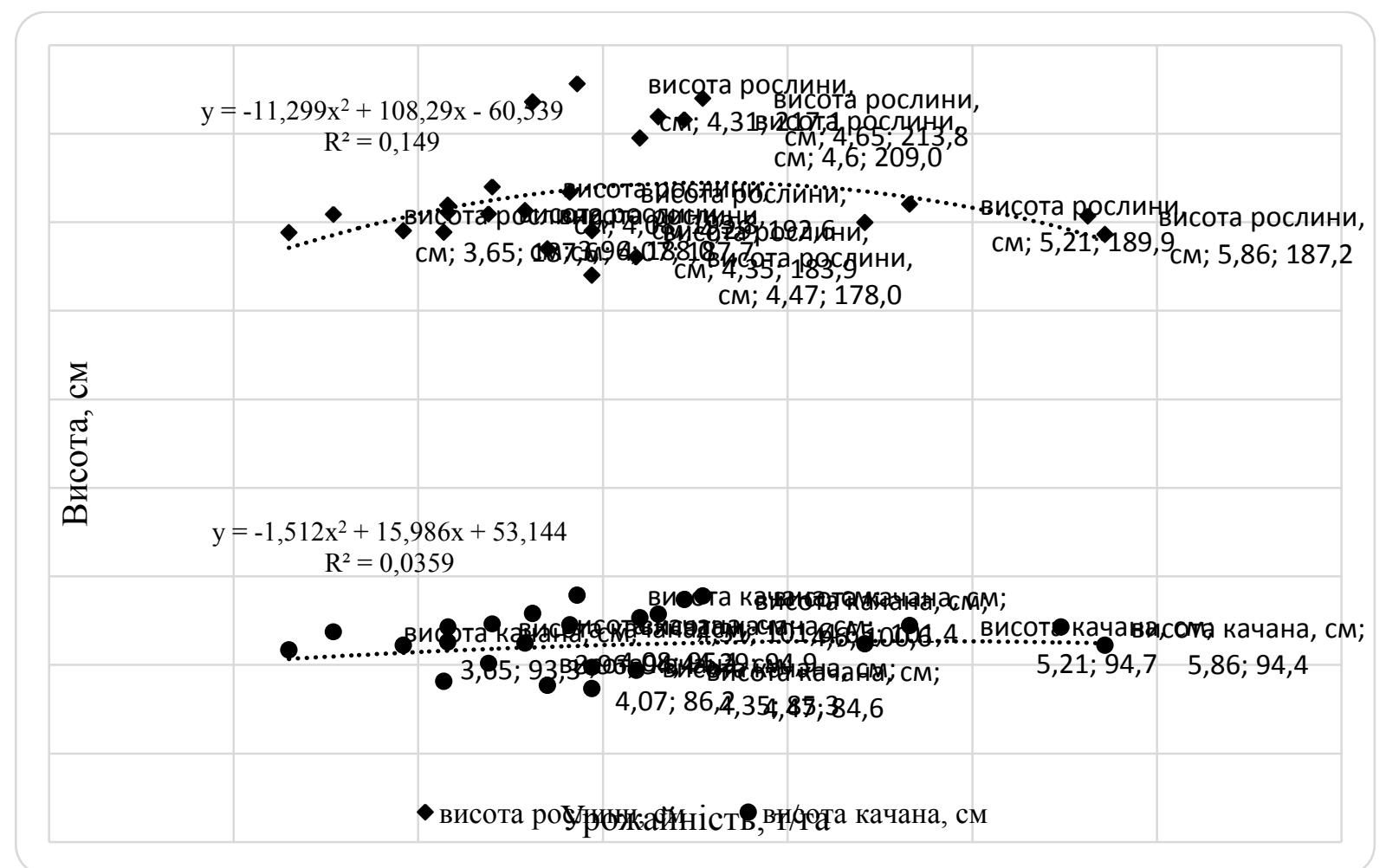

Fig. 1 Polynomial trend line describing the relationship of the plant height and cob attachment height in the parents of maize hybrids and seed yield, 2018-2020 average.

Notes. Висота, см - Height, cm; Урожайність, т/га - Yield, t/ha; Висота рослин, см - Plant height, cm; Висота качана, см - Cob attachment height, cm

The low correlation coefficient indicates the impossibility of visual pre-selections for performance driven by cob attachment height in the parents.

Analyzing our previous data on the plant and cob attachment heights in maize hybrids, we can conclude that the opposite pattern was observed for maize hybrids [23]. Hybrids Stepovyi, Skadovskyi, Arabat, Chongar, Vira, and Hileia (their parents are the studied lines) were found to have a close direct correlation between the plant height and grain yield. Thus, the correlation coefficient between the plant height and grain yield in these hybrids was +0.873 . The high correlation coefficient became possible primarily due to the positive effect of the growing period length on the plant height [24]. However, in the parents of these hybrids, the growing period did not play a decisive role in the plant height. In these hybrids, there was also a strong correlation between the cob attachment height and grain yield $(r=+0.741)$. The high correlation coefficient indicates the possibility of visual pre-selection for performance driven by cob attachment height in maize hybrids [25]. In maize lines, such visual assessment of performance is not possible.

Hence, the patterns of relationships and variability of the biometric traits in the hybrids and their parents are opposite on irrigation.

It was found that mid-late line DK 445 gave the highest seed yield of 4.11-6.30 t/ha (parent of hybrids Vira, Arabat, and Hileia), which was due to the extended growing period and optimized technology under irrigation (Table 3).

The gain in the seed yield, compared to the untreated control, was significantly influenced by biologicals - the gain in the seed yield from line DK 445 was $0.14-0.46 \mathrm{t} / \mathrm{ha}$ or $+3.2-10.3 \%$.

Helafit combi appears to be the most effective agent. Thus, in the mid-late group of parents, the highest seed yield was received from Helafit combi-treated line DK 445 (5.62 t/ha; yield increased by $0.85 \mathrm{t} / \mathrm{ha}$ or by $17.8 \%$ ). Helafit combi -treated line DK 411 gave $4.50 \mathrm{t} / \mathrm{ha}$ (yield increased by $0.36 \mathrm{t} / \mathrm{ha}$ or by $8.0 \%$ ). Helafit combi -treated mid-early line DK 247 gave a slightly lower yield ( $4.69 \mathrm{t} / \mathrm{ha}$; yield increased by $0.32 \mathrm{t} / \mathrm{ha}$ or by $6.8 \%)$. Helafit combi - treated earlyripening line DK 281 gave 4.05 t/ha (yield increased by 0.29 t/ha or by $7.2 \%$ ). The Bio-gelattributed gain in the yield was significantly lower. 
Table 3

Seed yields from the parents of maize hybrids depending on plant density and treatment with the biologicals, $t / h a,(2018-2020$ average)

\begin{tabular}{|c|c|c|c|c|c|c|}
\hline \multirow{2}{*}{$\begin{array}{c}\text { Parent } \\
\text { (factor A) }\end{array}$} & \multirow{2}{*}{$\begin{array}{c}\text { Plant } \\
\text { height, } \\
\text { plants/ha } \\
\text { (factor B) }\end{array}$} & \multicolumn{3}{|c|}{$\begin{array}{l}\text { Biological treatment } \\
\text { (factor } \mathrm{C})\end{array}$} & \multicolumn{2}{|c|}{ Factor average } \\
\hline & & $\begin{array}{l}\text { Control (no } \\
\text { treatment) }\end{array}$ & Bio-gel & $\begin{array}{l}\text { Helafit } \\
\text { combi }\end{array}$ & A & $\mathrm{B}$ \\
\hline DK 281 & 70,000 & 3.52 & 3.59 & 3.83 & \multirow{4}{*}{3.91} & 3.65 \\
\hline \multirow[t]{2}{*}{ (FAO 190) } & 80,000 & 3.82 & 3.92 & 4.13 & & 3.96 \\
\hline & 90,000 & 3.93 & 4.14 & 4.18 & & 4.08 \\
\hline Mean & & 3.76 & 3.88 & 4.05 & & \\
\hline DK 247 & 70,000 & 4.45 & 4.59 & 4.76 & \multirow{4}{*}{4.52} & 4.60 \\
\hline \multirow[t]{2}{*}{ (FAO 290) } & 80,000 & 4.42 & 4.65 & 4.89 & & 4.65 \\
\hline & 90,000 & 4.24 & 4.25 & 4.43 & & 4.31 \\
\hline Mean & & 4.37 & 4.50 & 4.69 & & \\
\hline \multirow{3}{*}{$\begin{array}{c}\text { DK } 411 \\
\text { (FAO 420) }\end{array}$} & 70,000 & 4.36 & 4.47 & 4.59 & \multirow{4}{*}{4.29} & 4.47 \\
\hline & 80,000 & 4.12 & 4.28 & 4.65 & & 4.35 \\
\hline & 90,000 & 3.95 & 3.99 & 4.26 & & 4.07 \\
\hline Mean & & 4.14 & 4.25 & 4.50 & & \\
\hline DK 445 & 70,000 & 5.56 & 5.73 & 6.30 & \multirow{4}{*}{5.12} & 5.86 \\
\hline \multirow[t]{2}{*}{$(\mathrm{FAO} 420)$} & 80,000 & 4.64 & 4.85 & 6.14 & & 5.21 \\
\hline & 90,000 & 4.11 & 4.35 & 4.42 & & 4.29 \\
\hline Mean & & 4.77 & 4.98 & 5.62 & & \\
\hline Factor $\mathrm{C}$ average & & 4.26 & 4.40 & 4.72 & & \\
\hline \multicolumn{7}{|c|}{ Significance of differences } \\
\hline $\mathrm{LDS}_{05}, \mathrm{t}$ & & $\mathrm{A}=0$ & $-0.25 ; \mathrm{B}=$ & $9-0.21 ;$ & $12-0.1$ & \\
\hline
\end{tabular}

The plant density plays an important role in the complex of agrotechnical measures influencing the yield in maize cultivation. Large yields of line seeds can be produced due to high individual performance and the maximum allowable density of plants under specific growing conditions.

On average across the study years, the highest seed yield was given by mid-late line DK445 at a density of 70,000 plants/ha $(5.86 \mathrm{t} / \mathrm{ha})$. At $80,000 \mathrm{plants} / \mathrm{ha}$, the yield was $5.21 \mathrm{t} / \mathrm{ha}$, while thickening to 90,000 plants/ha was associated with a sharp decrease in the yield to $4.29 \mathrm{t} / \mathrm{ha}$. Midlate line DK 411 also gave the maximum yield at a density of 70,000 plants/ha $(4.47 \mathrm{t} / \mathrm{ha})$. At 90,000 plants/ha, the yield was minimum (4.07 t/ha).

Mid-early line DK 247 gave the maximum yield at a plant density of 80,000 plants/ha. Earlyripening line DK 281 gave the maximum yield at a density of 90,000 plants/ha.

Analyzing the data, we can conclude that the plant density is closely related to the yield. Each group of ripeness has its optimal density of plants, and to obtain the maximum seed yield, one should stick to the optimal nutrition area for one plant. The most productive mid-late parents respond negatively to thickening.

Conclusions. Treatment of maize plants with biologicals has a positive effect on the plant height, cob attachment height and yields from the parents of maize hybrids.

Early-ripening line DK 281 (FAO 190) gave the maximum yield at a density of 90,000 plants/ha and treatment with Helafit combi (3.65 t/ha). Mid-early line DK 247 (FAO 290) gave the maximum yield at a density of 80,000 plants/ha and treatment with Helafit combi $(4.65 \mathrm{t} / \mathrm{ha})$. Midlate lines DK 445 and DK 411 gave the maximum yields at a density of 70,000 plants/ha and treatment with Helafit combi (6.30 t/ha and $4.65 \mathrm{t} / \mathrm{ha}$, respectively). 


\section{Список використаних джерел}

1. Lavrynenko Yu.O., Vozhegova R.A., Hozh O.A. Productivity of corn hybrids of different FAO groups depending on microfertilizers and growth stimulants under irrigation in the south of Ukraine. Agricultural Science and Practice. 2016. Vol. 3. № 1. P. 55-60. DOI: 10.15407/agrisp3.01.055.

2. Токмакова Л. М., Трепан А. О., Шевченко Л. А. Ефективність фосфорного живлення рослин кукурудзи за дії поліміксобактерину. Вісник Полтавської державної агарної академіï. 2019. № 1. C. 73-80. DOI:10.31210/visnyk2019.01.09.

3. Сухомуд О. Г., Адаменко Д. М., Кравець І. С., Суханов С. В. Вплив застосування мікродобрив ТМ «Актив-Урожай» на ріст, розвиток та урожайність рослин кукурудзи. Вісник Уманського національного університету садівнищтва. 2019. Т. 94, № 1. С. 156164. DOI:10.31395/2415-8240-2019-94-1-156-164.

4. Вожегова Р. А. Зрошуване землеробство - гарант продовольчої безпеки України в умовах змін клімату. Вісник аграрної науки. 2018. №11(788). С. 28-34. DOI: 10.31073/agrovisnyk201811-04.

5. Капустян М. В., Полухіна А. В., Тимчук В. М., Чернобай Л. М. Відпрацювання інструментарію та алгоритмів корегування селекційних програм по кукурудзі. Селекиія $i$ насінництво. 2018. Вип. 113. С. 77-84. DOI: 10.30835/2413-7510.2018.134360.

6. Milander J., Jukić Ž., Mason S. Hybrid maturity influence on maize yield and yield component response to plant population in Croatia and Nebraska. Cereal Research Communications. 2017. Vol. 45 № 2. P. 326-335. DOI:10.1556/0806.45.2017.015.

7. Паламарчук В. Д. Вплив позакореневих підживлень на кількість качанів у гібридів кукурудзи. Вісник аграрнӧ̈ науки. 2018. № 8. C. 24-32. DOI: 10.31073/agrovisnyk20180814.

8. Бєлов Я. В. Напрями оптимізації технологій вирощування кукурудзи за умов змін клімату. Вісник аграрної науки Причорномор'я. 2018. № 4. C. 74-81. DOI: 10.31521/2313092X/2018-4(100)-11.

9. Yi Q, Liu Y, Hou X, Zhang X, Li H, Zhang J. Genetic dissection of yield-related traits and midparent heterosis for those traits in maize (Zea mays L.). BMC plant biology. 2019. № 9. DOI: 10.1186/s12870-019-2009-2.

10. van Heerwaarden J., Hufford M. B., Ross-Ibarra J. Historical genomics of North American maize. Proc. Natl. Acad. Sci. USA. 2012. V. 109, Iss. 31. P. 12420-12425. DOI: 10.1073/ pnas. 1209275109.

11. Котченко М. В., Кірсанова Г. В., Пугач А. М., Пугач А. В. Продуктивність різностиглих гібридів кукурудзи в умовах Північного Степу України. Вісник Полтавської державної аграрної академії. 2016. № 4. С. 27-30. DOI:10.31210/visnyk2016.04.04.

12. Каленська С. М., Таран В. Г. Індекс урожайності гібридів кукурудзи залежно від густоти стояння рослин, норм добрив та погодних умов вирощування. Plant Varieties Studying and Protection. 2018. T. 14, № 4. C.415-421. DOI: 10.21498/2518-1017.14.4.2018.151909.

13. Пащенко Ю. М. Методика вирощування батьківських форм гібридів кукурудзи в Південному Степу. Селеки̧ія і насінництво. 2009. Т. 97. С. 203-208. doi:10.30835/24137510.2009 .77603$.

14. Mason S., Kmail Z., Galusha T., Jukić Ž. Path analysis of drought tolerant maize hybrid yield and yield components across planting dates. Journal of Central European Agriculture. 2019. Vol. 20, Iss. 1. P. 194-207. DOI: 10.5513/JCEA01/20.1.2106.

15. Pacific Seeds (2008/2009) Hybrid corn agronomy guide 2008/09, Pacific Seeds Pty Ltd, p. 24.

16. Widderick M., Meulen A van der., Churchett J., McLean A. Weed issues and action items. GRDC Update Papers 31 July. 2015. P. 35-36.

17. Савчук М. В., Лісовий М. М., Таран О. П., Чеченєва Т. М., Стародуб М. Ф. Вплив передпосівної обробки нанокомпозитами на фотосинтетичний апарат гібрида кукурудзи. Вісник аграрної науки. 2018. №5(782). C.32-35. DOI: 10.31073/agrovisnyk201805-05.

18. Lavrynenko Yu. O., Hozh O. A., Vozhegova R. A. Productivity of corn hybrids of different FAO groups depending on microfertilizers and growth stimulants under irrigation in the south of 
Ukraine. Agricultural science and practice. 2016. № 1. P. 55-60. DOI: 10.15407/agrisp3.01.055.

19. Vozhegova R. A., Lavrynenko Yu. O., Hlushko T. V. Productivity of maize hybrids of different FAO groups depending on condition of irrigation and dosage of fertilizers in the southern

20. Присяжнюк Л. М., Шовгун О. О., Король Л. В., Коровко І. І. Оцінка показників стабільності й пластичності нових гібридів кукурудзи (Zea mays L.) в умовах Полісся та Степу України. Plant Var. Stud. Prot. 2016. № 2. C. 16-21. DOI: 10.21498/25181017.2(31).2016.70050.

21. Лавриненко Ю. О., Коковіхін С. В., Найдьонов В. Г., Михайленко І. В. Наукові основи насінництва кукурудзи на зрошуваних землях півдня України. Херсон: Айлант, 2007. 256 c.

22. Методика польових і лабораторних досліджень на зрошуваних землях / Р. А. Вожегова, Ю. О. Лавриненко, М. П. Малярчук та ін. Херсон: Грінь Д. С., 2014. 268 с.

23. Марченко Т. Ю., Лавриненко Ю. О., Михайленко І. В., Хоменко Т. М. Біометричні показники гібридів кукурудзи різних груп ФАО залежно від обробки мікродобривами за умов зрошення. Plant Varieties Studying and Protection. Vol. 15, № 1. 2019. C. 71-79. DOI: 10.21498/2518-1017.15.1.2019.162486.

24. Marchenko T.Yu. Innovative elements of cultivation technology of corn hybrids of different FAO groups in the conditions of irrigation. Natural sciences and modern technological solutions: knowledge integration in the XXI century : collective monograph. Lviv-Torun : LihaPres, 2019. P. 137-153. DOI: 10.36059/978-966-397-154-4/135-152.

25. Marchenko T. Yu., Lavrynenko Yu.O., Tischenko A.V., Zabara P.P. Прояв і мінливість біометричних ознак у ліній-батьківських компонентів та гібридів кукурудзи за використання різних генетичних плазм при зрошенні. Наукові доповіді НУБІП України. 2020. №3 (85). ISSN: 2223-1609. DOI: 10.31548/dopovidi2020.03.008.

\section{Referens}

1. Lavrynenko YuO, Vozhegova RA, Hozh OA. Productivity of corn hybrids of different FAO groups depending on microfertilizers and growth stimulants under irrigation in the south of Ukraine. Agricultural Science and Practice. 2016; 3(1): 55-60. DOI: 10.15407/agrisp3.01.055.

2. Tokmakova LM, Trepan AO, Shevchenko LA. The effectiveness of phosphorus nutrition of polymyxobacterin-teated corn plants. Visnyk Poltavskoi derzhavnoi aharnoi akademii. 2019; 1 : 73-80. DOI:10.31210/visnyk2019.01.09.

3. Sukhomud OH, Adamenko DM, Kravets IS, Sukhanov SV. Influence of microfertilizers of TM "Aktyv-Urozhai" on the growth, development and performance of corn plants. Visnyk Umanskoho natsionalnoho universytetu sadivnytstva. 2019; 94: 156-164. DOI:10.31395/24158240-2019-94-1-156-164.

4. Vozhehova RA. Irrigated agriculture is the guarantor of the food security of Ukraine under climatic changes. Visnyk ahrarnoi nauky. 2018; №11(788): 28-34. DOI: 10.31073/agrovisnyk201811-04.

5. Kapustian MV, Polukhina AV, Tymchuk VM, Chernobai LM. Development of tools and algorithms for adjusting corn breeding programs. Sel. Nasinn. 2018; 113: 77-84. DOI: 10.30835/2413-7510.2018.134360.

6. Milander J, Jukić Ž, Mason S. Hybrid maturity influence on maize yield and yield component response to plant population in Croatia and Nebraska. Cereal Research Communications. 2017; 45(2): 326-335. DOI: 10.1556/0806.45.2017.015.

7. Palamarchuk VD. Influence of foliar supplementary fertilization on the cob number in maize hybrids. Visnyk ahrarnoi nauky. 2018; 8: 24-32. DOI: 10.31073/agrovisnyk201808-14.

8. Bielov YaV. Avenues of optimization of corn growing technologies under climatic changes. Visnyk ahrarnoi nauky Prychornomoria. 2018; 4: 74-81. DOI: 10.31521/2313-092X/20184(100)-11.

9. Yi Q, Liu Y, Hou X, Zhang X, Li H, Zhang J. Genetic dissection of yield-related traits and midparent heterosis for those traits in maize (Zea mays L.). BMC plant biology. 2019; 9. DOI: 10.1186/s12870-019-2009-2. 
10. Van Heerwaarden J, Hufford MB, Ross-Ibarra J. Historical genomics of North American maize. Proc. Natl. Acad. Sci. USA. 2012; 109(31): 12420-12425. DOI: 10.1073/ pnas.1209275109.

11. Kotchenko MV, Kirsanova HV, Puhach AM, Puhach AV. Performance of differently ripening corn hybrids in the Northern Steppe of Ukraine. Visnyk Poltavskoi derzhavnoi ahrarnoi akademii. 2016; 4: 27-30. DOI:10.31210/visnyk2016.04.04.

12. Kalenska SM, Taran VH. Yield index of maize hybrids depending on plant density, fertilizer doses and weather conditions of cultivation. Plant Varieties Studying and Protection. 2018; 14(4): 415-421. DOI: 10.21498/2518-1017.14.4.2018.151909.

13. Pashchenko YuM. Cultivation methods for maize hybrid parents in the Southern Steppe. Selektsiia i nasinnytstvo. 2009; 97: 203-208. DOI: 10.30835/2413-7510.2009.77603.

14. Mason S, Kmail Z, Galusha T, Jukić Ž. Path analysis of drought tolerant maize hybrid yield and yield components across planting dates. Journal of Central European Agriculture. 2019; 20(1): 194-207. DOI: 10.5513/JCEA01/20.1.2106.

15. Pacific Seeds (2008/2009) Hybrid corn agronomy guide 2008/09, Pacific Seeds Pty Ltd, p. 24.

16. Widderick M, Meulen A van der, Churchett J, McLean A. Weed issues and action items. GRDC Update Papers 31 July. 2015; 35-36.

17. Savchuk MV, Lisovyi MM, Taran OP, Chechenieva TM, Starodub MF. Effect of pre-sowing treatment with nanocomposites on the photosynthetic apparatus in a maize hybrid. Visnyk ahrarnoi nauky. 2018; № 5(782): 32-35. DOI: 10.31073/agrovisnyk201805-05.

18. Lavrynenko YuO, Hozh OA, Vozhegova RA. Productivity of corn hybrids of different FAO groups depending on microfertilizers and growth stimulants under irrigation in the south of Ukraine. Agricultural science and practice. 2016; 1: 55-60. DOI: 10.15407/agrisp3.01.055.

19. Vozhegova RA, Lavrynenko YuO, Hlushko TV. Productivity of maize hybrids of different FAO groups depending on condition of irrigation and dosage of fertilizers in the southern steppe of Ukraine. Agric. Sci. Pract. 2014; 1(3): 62-68. DOI: 10.15407/agrisp1.03.062.

20. Prysiazhniuk LM, Shovhun OO, Korol LV, Korovko II. Assessment of stability and plasticity indicators in new corn (Zea mays L.) hybrids in the woodlands and steppe of Ukraine. Plant Var. Stud. Prot. 2016; 2: 16-21. DOI: 10.21498/2518-1017.2(31).2016.70050.

21. Lavrynenko YuO, Kokovikhin SV, Naidonov VH, Mykhailenko IV. Scientific basics of corn seed production on irrigated lands in the South of Ukraine. Kherson: Ailant, 2007; 256.

22. Methods of field and laboratory studies on irrigated lands. In: RA Vozhehova, YuO Lavrynenko, MP Maliarchuk et al., eds. Kherson: Hrin DS, 2014. 268 p.

23. Marchenko TYu, Lavrynenko YuO, Mykhailenko IV, Khomenko TM. Biometric indicators of maize hybrids of different FAO groups depending on micronutrient treatment on irrigation. Plant Varieties Studying and protection. 2019; 15(1): 71-79. DOI: 10.21498/25181017.15.1.2019.162486.

24. Marchenko TYu. Expression and variability of biometric traits in maize parents and hybrids evolved from different genetic plasms on irrigation. Natural sciences and modern technological solutions: knowledge integration in the XXI century : collective monograph. Lviv-Torun : LihaPres, 2019. P. 137-153. DOI: 10.36059/978-966-397-154-4/135-152.

25. Marchenko TYu, Lavrynenko YuO, Tischenko AV, Zabara РP. Прояв і мінливість біометричних ознак у ліній-батьківських компонентів та гібридів кукурудзи за використання різних генетичних плазм при зрошенні. Наукові доповіді НУБІП Украӥни. 2020. №3 (85). ISSN: 2223-1609. http://dx.doi.org/10.31548/dopovidi2020.03.008. 
Марченко Т.Ю., Вожегова Р.А., Лавриненко Ю.О., Забара П.П.

Інститут зрошуваного землеробства НААН, Україна

Мета і задачі дослідження. Метою досліджень було встановлення біометричних показників та урожайності насіння ліній-батьківських компонентів сучасних вітчизняних гібридів кукурудзи різних груп стиглості, за різної густоти рослин та обробітку біопрепаратами на краплинному зрошенні в умовах Південного Степу. Визначити взаємозв'язки висоти рослин та висоти прикріплення верхнього (продуктивного) качана 3 урожайністю насіння ліній-батьківських компонентів гібридів.

Матеріали та методи. Дослідження проводились протягом 2018-2020 pp. на дослідному полі Інституту зрошуваного землеробства НААН, що розташоване в зоні Інгулецького зрошувального масиву. Грунт дослідної ділянки темно-каштановий средньосуглинковий слабкосолонцюватий з глибоким рівням залягання грунтових вод.

Трьохфакторний дослід закладали методом рендомізованих розщеплених блоків. Дослідження проводили у чотириразовій повторності. Посівна площа ділянок $30,0 \mathrm{~m}^{2}$, облікова - 20,0 м².

Фактор А - різні за групами стиглості лінії-батьківські форми: ДК 445 (батьківський компонент гібридів Арабат, Віра, Гілея); ДК 411 (батьківський компонент гібридів Чонгар, Ламасан); ДК 281 (батьківський компонент гібриду Степовий); ДК 247 (батьківський компонент гібриду Скадовський). Фактор В - густота рослин батьківських компонентів 70, 80, 90 тис. шт/га. Фактор С - обробка батьківських компонентів кукурудзи біологічними препаратами: Біо-гель, Хелафіт комбі, що занесені до Реєстру дозволених для використання пестицидів.

Обговорення результатів. Обробка рослин кукурудзи біопрепаратами позитивно вплинула на висоту батьківських компонентів за окремими фазами розвитку. Найбільший вплив на ростові процеси спричиняв препарат Хелафіт форте, який забезпечував збільшення висоти рослин порівняно 3 контролем на 1,9-3,8 см. Біо-гель, в середньому за дослідом, мінімально впливав на ростові процеси (приріст 0,3-2,4 см).

Ранньостигла лінія ДК 281 (ФАО 190) максимальну урожайність показала за густоти 90 тис. p./га і обробки препаратом Хелафіт комбі - 3,65 т/га. Середньорання лінія ДК 247 (ФАО 290) максимальну врожайність показала за густоти 80 тис. р./га та обробки препаратом Хелафіт комбі - 4,65 т/га. Середньопізні лінії ДК 445 та ДК 411 максимальну врожайність показали за густоти 70 тис. p/га і обробки препаратом Хелафіт комбі - 6,30 т/га та 4,65 т/га відповідно.

Висновки. Встановлено біометричні показники та урожайність насіння ліній-батьківських компонентів сучасних вітчизняних гібридів кукурудзи різних груп стиглості, за різної густоти рослин та обробітку біопрепаратами на краплинному зрошенні в умовах Південного Степу. Визначено взаємозв'язки висоти рослин та висоти прикріплення верхнього (продуктивного) качана з урожайністю насіння ліній-батьківських компонентів гібридів.

Ключові слова: кукурудза, батьківський компонент, висота рослини, висота верхнього (продуктивного качана), урожайність 
Марченко Т.Ю., Вожегова Р.А., Лавриненко Ю.А., Забара П.П.

Институт орошаемого земледелия Национальной академии аграрных наук, Украина

Цель и задачи исследования. Установление биометрических показателей и урожайности семян линий - родительских компонентов современных отечественных гибридов кукурузы разных групп спелости при разной густоте растений и обработке биопрепаратами на капельном орошении в условиях Южной Степи Украины. Установить взаимосвязь высоты растений и высоты прикрепления верхнего (продуктивного) початка с урожайностью семян линий - родительских компонентов гибридов.

Материалы и методы. Исследования проводили в 2018-2020 гг. на опытном поле Института орошаемого земледлия НААН, расположенном в зоне Ингулецкого орошаемого массива.

Трехфакторный опыт закладывали методом рендомизированных расщепленных блоков. Повторение четырехкратное, площадь делянок $30,0 \mathrm{~m}^{2}$, учетная $-20,0 \mathrm{~m}^{2}$.

Фактор А - разные по группам спелости линии - родительские компоненты ДК 445, ДК 411, ДК 281, ДК 247. Фактор В - густота растений родительских компонентов 70, 80, 90 тыс. шт/га. Фактор C - обработка родительских компонентов кукурузы биопрепаратами Биогель, Хелафит комби, внесенных в Реестр разрешенных к использованию пестицидов.

Обсуждение результатов. Обработка растений кукурузы биопрепаратами положительно повлияла на высоту родительских компонентов. Наиболее значительным было влияние на ростовые процессы препарата Хелафит форте, обспечивающего увеличение высоты растений в сравнении с контролем на 1,9-3,8 см. Био-гель, в среднем по опыту, минимально влиял на ростовые процессы (прирост 0,3-2,4 см).

Раннеспелая линия ДК 281 (ФАО 190) максимальную урожайность имела при густоте 90 тыс. p./га и обработке препаратом Хелафит комби - 3,65 т/га. Среднеранняя линия ДК 247 (ФАО 290) максимальную урожайность формировала при густоте 80 тыс. р./га и обработке также Хелафіт комбі - 4,65 т/га. Среднепоздние линии ДК 445 и ДК 411 - при густоте 70 тыс. р/га и Хелафит комби - 6,30 т/га и 4,65 т/га соответственно.

Выводы. Установлены биометрические показатели и урожайность семян линийродительских компонентов современных отечественных гибридов кукурузы различных групп спелости при различной густоте растений и обработке биопрепаратами на капельном орошении в условиях Южной Степи. Определены взаимосвязи высоты растений и высоты прикрепления верхнего (продуктивного) початка с урожайностью семян линий-родительских компонентов гибридов.

Ключевые слова: кукуруза, родительский компонент, высота растения, высота верхнего (продуктивного початка), урожайность

\section{BIOMETRIC INDICATORS OF LINES - PARENTS OF MAIZE HYBRIDS OF DIFFERENT FAO GROUPS DEPENDING ON BIOLOGICAL TREATMENT ON IRRIGATION}

Marchenko T., Vozhegova R., Lavrynenko Y., Zabara P.

Institute of Irrigated Agriculture of the National Academy of Agrarian Sciences, Ukraine

Purpose and objectives. Our purpose was to determine biometric indicators and seed yields of parents of modern domestic maize hybrids belonging to different ripeness groups, grown at various plant densities on drip irrigation in the Southern Steppe and treated with biologicals; to evaluate the relationships between the plant height and the attachment height of the upper (productive) cob with the seed yield in the lines - parents of hybrids.

Materials and methods. The study was conducted in the experimental field the Institute of 
Irrigated Agriculture of NAAS located in the area of Inhuletkyi irrigation system in 2018-2020. The soil in the experimental site is dark-chestnut, medium loamy, slightly alkalinized, with deep groundwater levels.

The design of a three-factor experiment was randomized split blocks, in quadruplicate. The sown plot area was $30.0 \mathrm{~m}^{2}$; the record area was $20.0 \mathrm{~m}^{2}$.

Factor A - lines-parents of different ripeness groups: DK 445 (parent of hybrids Arabat, Vira, Hileia), DK 411 (parent of hybrids Chonhar, Lamasan), DK 281 (parent of hybrid Stepovyi), and DK 247 (parent of hybrid Skadovskyi). Factor B - plant density of the parents $(70,000,80,000$ and 90,000 plants/ha). Factor $\mathrm{C}$ - treatment of the parents with biologicals: Bio-gel and Helafit combi, which are in the Permitted Pesticide Register.

Results and discussion. Biometric indicators and seed yield of parental components of modern domestic maize hybrids of different maturity groups, at different plant densities and treatment with biological products on drip irrigation in the Southern Steppe have been established. The relationship between plant height and the height of attachment of the upper (productive) cob with the seed yield of the lines of the parent components of hybrids was determined. Studies have shown that treatment of maize plants with biological products has a positive effect on plant height, height of attachment of the cob and the yield of the parent forms of maize hybrids. Earlymaturing line DK 281 (FAO 190) showed the maximum yield at densities of 90 thousand $\mathrm{g} / \mathrm{ha}$ and treatment with the drug Helafit combi $-3.65 \mathrm{t} / \mathrm{ha}$. The middle-early line DK 247 (FAO 290) showed the maximum yield at densities of 80 thousand $\mathrm{g} / \mathrm{ha}$ and treatment with Helafit combi 4.65 t/ha. Mid-late lines DK 445 and DK 411 showed the maximum yield at densities of 70 thousand $\mathrm{g} / \mathrm{ha}$ and treatment with Helafit combi $-6.30 \mathrm{t} / \mathrm{ha}$ and $4.65 \mathrm{t} / \mathrm{ha}$, respectively.

Conclusions. Biometric indicators and seed yields of parents of modern domestic maize hybrids of different ripeness groups grown at various plant densities on drip irrigation in the Southern Steppe and treated with biologicals have been determined. The relationships between the plant height and the attachment height of the upper (productive) cob with the seed yields in the lines parents of hybrids have been established.

Key words: maize, parental component, plant height, height of upper (productive cob), yield 